\title{
Compressive Strength of Geopolymer Based on the Fly Ash Variation ANTONI $^{1, a *}$, STEPHEN Wibiatma Wijaya ${ }^{2, b}$ and DJWANTORO Hardjito ${ }^{1, c}$ \\ 1 Department of Civil Engineering, Petra Christian University, Indonesia \\ ${ }^{2}$ Post Graduate Program in Civil Engineering, Petra Christian University, Indonesia \\ aantoni@petra.ac.id, bstephen.wibi@yahoo.com, 'djwantoro.h@petra.ac.id
}

\begin{abstract}
Keywords: geopolymer, fly ash, $\mathrm{CaO}$ content, specific surface area, strength
\end{abstract}
\begin{abstract}
This study was conducted to determine the factors that may affect the compressive strength of fly ash-based geopolymer. With so many kinds of fly ash available and has its different characteristics, it would be very influential on geopolymer produced. These effects is classified into internal and external of the fly ash material. Internal influences include the physical and chemical properties of the fly ash, while external influences associated with mixture of geopolymer and the manufacturing process. From the experiment results, it was found that the size of the granules, the content of $\mathrm{CaO}$ and $\mathrm{MgO}$, and carbon content in fly ash that are internal factors that may affect the compressive strength. While the ratio of sodium silicate and sodium hydroxide in the alkaline solution and $\mathrm{NaOH}$ molarity used can also give a direct influence on the compressive strength of geopolymer.
\end{abstract}

\section{Introduction}

One of the use of fly ash is as a raw material for manufacturing geopolymer concrete, because the fly ash contains silica ( $\mathrm{Si}$ ) and alumina (Al) so it can form a polymerization reaction when mixed with strong alkali [1]. In the making of geopolymer concrete, the quality of fly ash used, both physical and chemical characteristics influence the process and the end result. In general, the characteristics of fly ash is closely related to the type of coal used. This is consistent with studies that have been carried out [2] that the physical properties and chemical content of fly ash influenced from the type of coal, coal burning techniques, the mineral content, method of collection, long storage time, and the sampling period. Therefore, although the fly ash comes from the same place can have different characteristics.

Reactivity of fly ash in its use as a geopolymer concrete is also greatly influenced by the particle size (surface area), the content of amorphous materials (glass content), and the chemical composition of the constituent (glass composition) [3]. The main chemical content in fly ash in the form of $\mathrm{SiO}_{2}, \mathrm{Fe}_{2} \mathrm{O}_{3}$ and $\mathrm{Al}_{2} \mathrm{O}_{3}$ are generally used to classify the fly ash type. The content of $\mathrm{CaO}$ also contribute to the characteristics of the fly ash. In previous studies [4,5], high levels $\mathrm{CaO}$ in fly ash has an advantage that it can produce high compressive strength, because the polymerization reaction and hydration reaction occurs together. $\mathrm{CaO}$ content is related to the $\mathrm{pH}$ value measured in fly ash $[6,7]$.

In the formation of geopolymer concrete, alkaline activator is needed as an activator of the polymerization reaction of silica and alumina contained in fly ash. The alkaline solution most commonly used is a combination of sodium hydroxide $(\mathrm{NaOH})$ and sodium silicate $\left(\mathrm{Na}_{2} \mathrm{SiO}_{3}\right)$. With the high concentration (molarity) of a sodium hydroxide solution, the resulting compressive strength also becomes higher. Similarly, the ratio between sodium silicate and sodium hydroxide, with higher ratios used, produce geopolymer concrete compressive strength of the higher [8]. By looking at various factors that could potentially affect the compressive strength of geopolymer, this study intends to determine the contribution of these factors from the properties of the fly ash and the mixture composition. 


\section{Experimental Method}

Material. Fly ash used as a base material in this study came from different coal power plant in East Java. Five types of fly ash originating from Paiton, Probolinggo unit 5\&6 (coded Y11.2 and Y9.8), Paiton unit 1\&2 (coded P10.3), Tanjung Jati, Jepara (coded J10.6) and Rembang (coded R9.6). Each fly ash was coded in addition with the $\mathrm{pH}$ measured in aqueous solution of $20 \mathrm{gr}$ fly ash in $80 \mathrm{ml}$ deionized water. In each fly ash sample, physical testing such as particle size distribution, specific gravity and scanning electron microscope (SEM) was conducted. In addition to the physical examination, $\mathrm{x}$-ray fluorescence (XRF) also was conducted to see the chemical content of fly ash. Results of XRF and the physical properties of the fly ash can be seen in Table 1. Results of the SEM is shown in the Fig. 1.

Table 1. Fly Ash chemical composition and physical properties

\begin{tabular}{cccccc}
\hline Oxide (\%) & Fly ash Y11.2 & Fly ash J10.6 & Fly ash P10.3 & Fly ash Y9.8 & Fly ash R9.6 \\
\hline $\mathrm{SiO}_{2}$ & 39.78 & 38.24 & 51.03 & 51.12 & 50.14 \\
$\mathrm{Al}_{2} \mathrm{O}_{3}$ & 17.87 & 15.28 & 25.13 & 18.90 & 29.08 \\
$\mathrm{Fe}_{2} \mathrm{O}_{3}$ & 15.00 & 24.28 & 9.66 & 17.71 & 9.66 \\
$\mathrm{CaO}$ & 15.47 & 9.15 & 5.49 & 5.54 & 4.03 \\
$\mathrm{~K}_{2} \mathrm{O}$ & 1.32 & 0.78 & 1.58 & 0.82 & 1.53 \\
$\mathrm{MgO}$ & 6.45 & 5.19 & 3.25 & 3.17 & 1.11 \\
$\mathrm{SO}_{3}$ & 1.32 & 0.61 & 0.51 & 0.47 & 0.77 \\
$\mathrm{MnO}_{2}$ & 0.18 & 0.37 & 0.12 & 0.33 & 0.06 \\
$\mathrm{TiO}_{2}$ & 0.73 & 0.81 & 1.16 & 0.98 & 1.51 \\
$\mathrm{Cr}_{2} \mathrm{O}_{3}$ & 0.02 & 0.02 & 0.02 & 0.03 & 0.02 \\
$\mathrm{Na}_{2} \mathrm{O}$ & 1.51 & 0.80 & 1.51 & 0.63 & 0.80 \\
$\mathrm{LOI}$ & 0.49 & 3.90 & 1.44 & 6.96 & 0.63 \\
\hline $\mathrm{SSA}\left(\mathrm{kg} / \mathrm{m}^{2}\right)$ & 2618 & 2078 & 1370 & 1785 & 1169 \\
$\mathrm{D}_{\mathrm{v}}(50)(\mu \mathrm{m})$ & 6.98 & 8.03 & 20.1 & 10.3 & 19.2 \\
$\mathrm{D}_{\mathrm{v}}(90)(\mu \mathrm{m})$ & 60.8 & 63.5 & 136 & 84.3 & 104 \\
$\mathrm{Specific} \mathrm{gravity}$ & 2.63 & 2.915 & 2.489 & 2.36 & 2.245 \\
\hline
\end{tabular}
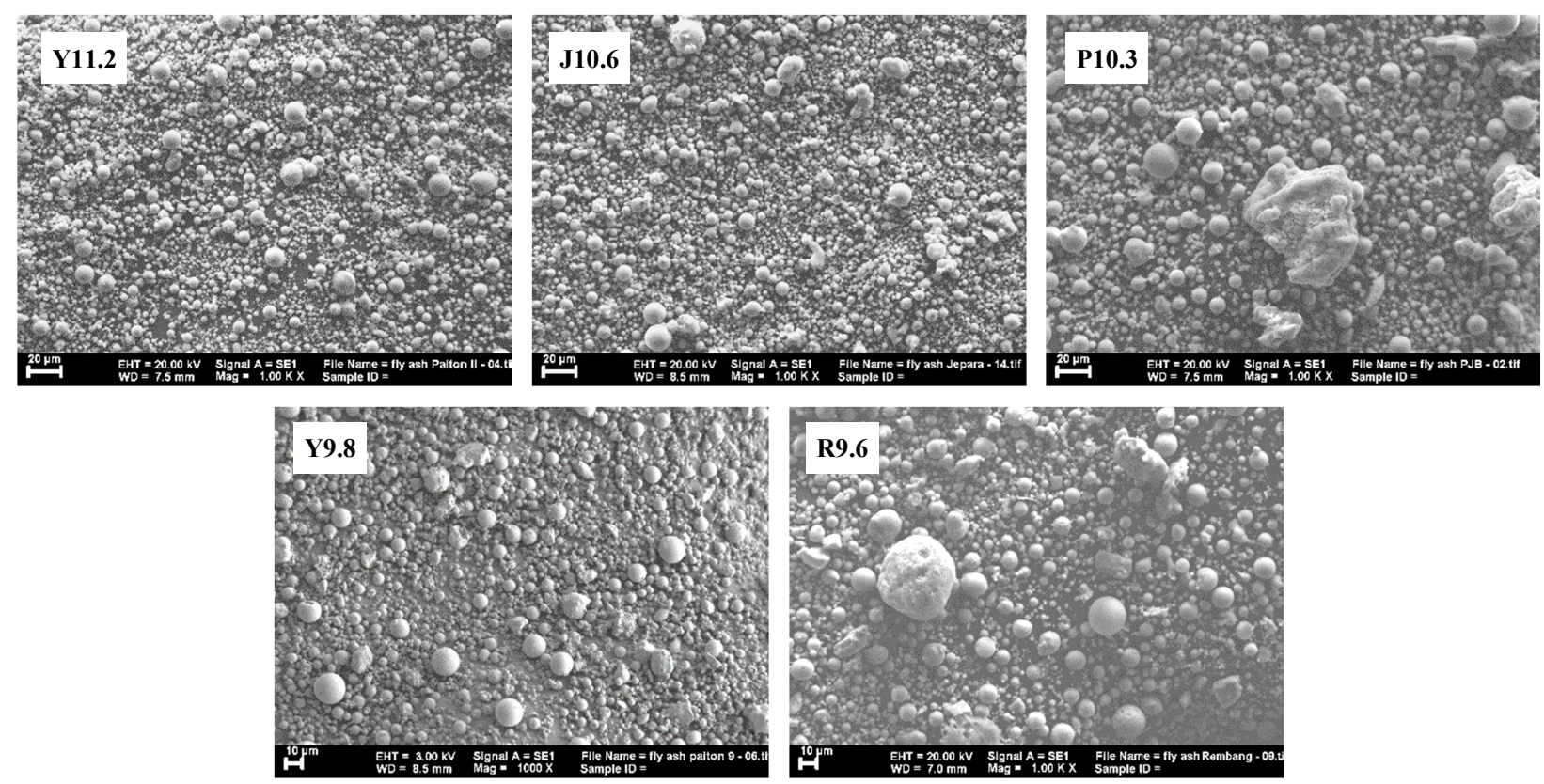

Figure 1. SEM micrograph of the fly ash used.

From the SEM photo it can be seen that it have some correlation with the specific surface area (SSA) measured. The greater the value of SSA shows that grains are also finer. The SEM also shows that each sample of fly ash has a different form of particle shape, especially on fly ash R9.6 and P10.3, which have some irregular shape particle and larger globule. 
According to the standard ASTM C618 [9], the classification of fly ash based on the content of the main chemical compound in the form of $\mathrm{SiO}_{2}, \mathrm{Fe}_{2} \mathrm{O}_{3}$ and $\mathrm{Al}_{2} \mathrm{O}_{3}$. Samples of fly ash used meets the standards of the three main compounds in which the number is more than $70 \%$, while based on the content of $\mathrm{CaO}$, fly ash $\mathrm{Y} 11,2$ is classified as type $\mathrm{C}$ fly ash, while the remaining four is type $\mathrm{F}$ fly ash.

Sand from Lumajang in saturated surface dry (SSD) condition and fineness modulus of 2.52 was used for making all of the mixture. Alkaline solution as an activator of the polymerization reaction was made from solution of sodium hydroxide $(\mathrm{NaOH})$ and sodium silicate $\left(\mathrm{Na}_{2} \mathrm{SiO}_{3}\right)$.

Mix proportion. The experimental study was conducted in geopolymer mortar were made in accordance with a mixture of solution to binder ratio of 0.25 , sand to binder ratio of 2 for all fly ash type. Sodium hydroxide $(\mathrm{NaOH})$ solid were dissolved in water with molarity of $8 \mathrm{M}$ one day prior mixing. Ratio of alkaline solution which are Sodium Silicate liquid to Sodium Hydroxide solid $\left(\mathrm{Na}_{2} \mathrm{SiO}_{3} / \mathrm{NaOH}\right)$ used is $1 ; 1.5$; and 2 .

Specimen preparation and testing. The $\mathrm{NaOH}$ solution in accordance with a predetermined ratio was made one day before mixing. Fine aggregate and fly ash is mixed in advance to make a uniform dried material. Mixing an alkaline solution containing sodium hydroxide liquid and sodium silicate liquid was done prior mixing with the binder and then with the aid of a hand drill and a table vibrator all material are mix to ensure uniform mixing and all done in less than 5 minutes. Casting is done on the cube formwork measuring $50 \times 50 \times 50 \mathrm{~mm}$. After casting, plastic sheet was wrapped in the formwork to avoid excessive evaporation. Curing was done in oven with a temperature of $60^{\circ} \mathrm{C}$ for 24 hours. After that, the specimen can be demolded and it was stored at room temperature until testing time. Compressive strength testing conducted on mortar aged 3, 7 and 14 days. From each mix design, three specimens are averaged to obtain the compressive strength data.

\section{Results and Discussions}

Compressive strength. The compressive strength result is shown in Table 2. There is a wide range of the strength result based on the composition and material source. Lower strength was expected from lower ratio of sodium silicate to sodium hydroxide, but the trend of increment was not same for each fly ash used. There are some strength increase even using oven curing for 3 days, 7 days and 14 days testing.

Table 2. Compressive strength of the geopolymer mortar

\begin{tabular}{|c|c|c|c|c|c|c|}
\hline \multirow{2}{*}{ Fly ash } & \multirow{2}{*}{$w / b$} & \multirow{2}{*}{$\begin{array}{c}\mathrm{NaOH} \\
\text { concentration }\end{array}$} & \multirow{2}{*}{$\mathrm{Na}_{2} \mathrm{SiO}_{3} / \mathrm{NaOH}$} & \multicolumn{3}{|c|}{ Compressive strength (MPa) } \\
\hline & & & & 3 days & 7 days & 14 days \\
\hline \multirow{3}{*}{ Fly ash Y11.2 } & \multirow{3}{*}{0,25} & \multirow{3}{*}{$8 \mathrm{M}$} & 1 & 45.80 & 36.20 & 48.00 \\
\hline & & & 1,5 & 75.33 & 79.33 & 86.00 \\
\hline & & & 2 & 78.00 & 88.40 & 98.00 \\
\hline \multirow{3}{*}{ Fly ash J10.6 } & \multirow{3}{*}{0,25} & \multirow{3}{*}{$8 \mathrm{M}$} & 1 & 4.27 & 4.93 & 8.27 \\
\hline & & & 1,5 & 25.60 & 37.33 & 44.67 \\
\hline & & & 2 & 42.67 & 47.33 & 54.67 \\
\hline \multirow{3}{*}{ Fly ash P10.3 } & \multirow{3}{*}{0,25} & \multirow{3}{*}{$8 \mathrm{M}$} & 1 & 4.67 & 6.67 & 7.33 \\
\hline & & & 1,5 & 23.33 & 25.87 & 31.33 \\
\hline & & & 2 & 37.33 & 44.00 & 42.00 \\
\hline \multirow{3}{*}{ Fly ash Y9.8 } & \multirow{3}{*}{0,25} & \multirow{3}{*}{$8 \mathrm{M}$} & 1 & 13.60 & 15.60 & 25.07 \\
\hline & & & 1,5 & 30.00 & 33.07 & 40.00 \\
\hline & & & 2 & 38.00 & 43.60 & 50.27 \\
\hline \multirow{3}{*}{ Fly ash R9.6 } & \multirow{3}{*}{0,25} & \multirow{3}{*}{$8 \mathrm{M}$} & 1 & 12.40 & 16.00 & 17.40 \\
\hline & & & 1,5 & 20.67 & 22.00 & 37.07 \\
\hline & & & 2 & 26.00 & 40.00 & 56.40 \\
\hline
\end{tabular}

Internal effect is defined as the internal influences derived from fly ash used. Physical and chemical properties of the fly ash itself will greatly affect the results obtained. The influence of 
physical properties of fly ash is shown in Fig. 2(a). With the finer particle size of fly ash shown by the higher value of SSA, showed a strong prospect in achieving higher compressive strength.
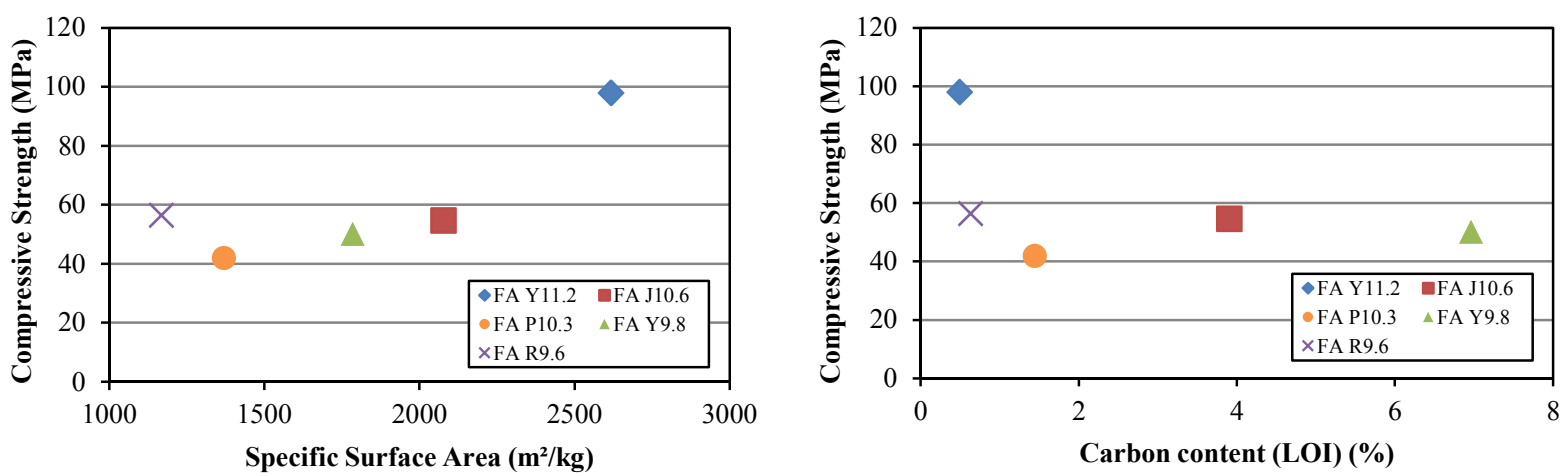

Figure 2. Compressive strength at 14 days with relation to (a) Specific surface area and (b) Lost on ignition of the fly ash.
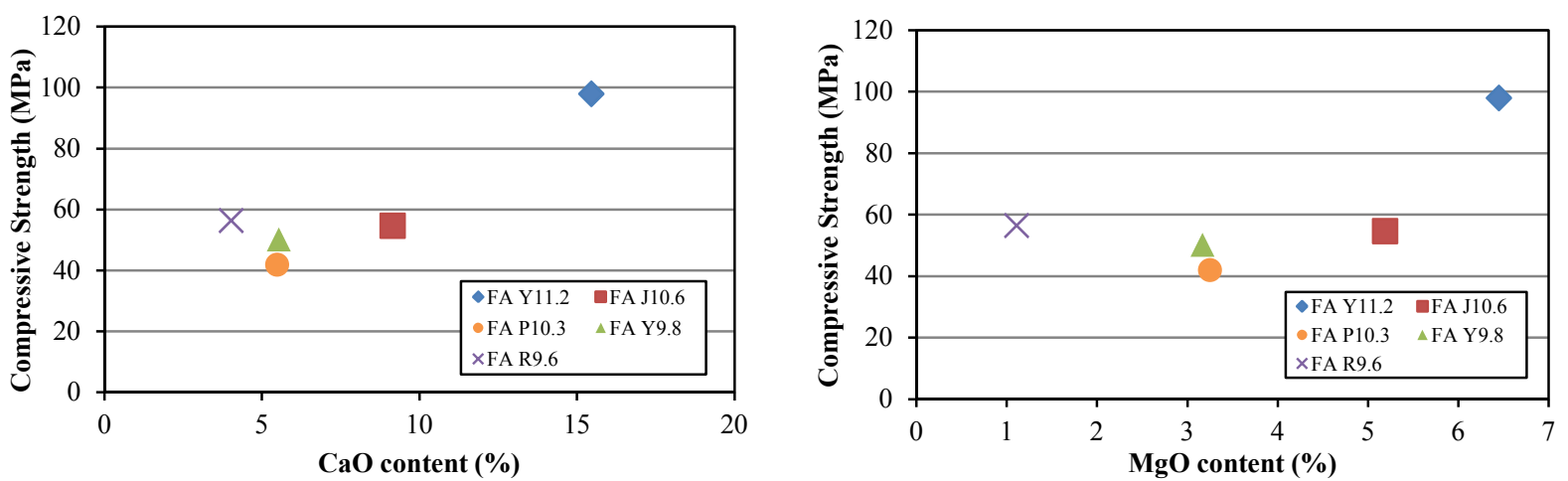

Figure 3. Compressive strength at 14 days with relation to (a) $\mathrm{CaO}$ content and

(b) $\mathrm{MgO}$ content of the fly ash.

Combustible material contained in fly ash is shown as the LOI value, where the higher the LOI value shows a high carbon content in fly ash. Fly ash Y11.2 and R9.6 have LOI value of $0.49 \%$ and $0.63 \%$, which shows the content of which is quite low compared to other samples of fly ash which has a LOI value above $1.00 \%$. By looking at the correlation between LOI content with the compressive strength of mortar produced as shown in Fig. 2(b), it was shown to have slight tendency that with lower carbon content in fly ash produces a higher compressive strength, especially with the content of below $1 \%$.

The XRF test results also show the constituent chemical compounds content of fly ash. The content of $\mathrm{CaO}$ and $\mathrm{MgO}$ is shown to be directly proportional to the $\mathrm{pH}$ value of fly ash. With the higher the content of $\mathrm{CaO}$ and $\mathrm{MgO}$, the $\mathrm{pH}$ value of fly ash is also higher. Furthermore, when it was correlated with the compressive strength result as shown in Fig. 3, it was recorded that content of $\mathrm{CaO}$ and $\mathrm{MgO}$ in the fly ash can affect the compressive strength in geopolymer because $\mathrm{CaO}$ also affects the reactivity possessed by the fly ash [9]. The higher $\mathrm{CaO}$ content would cause not only polymerization reaction but also hydration reaction that can improve the compressive strength obtained. However, the $\mathrm{MgO}$ content in fly ash is not yet known to have beneficial effect on the compressive strength because effect of $\mathrm{MgO}$ on the geopolymer could also compensate the geopolymer shrinkage [10].

For the record, the use of five kinds of fly ash in this research have significant different sources and chemical content. The higher strength could be influenced from the combination of several factors.

External effect is defined as the effect of the mixture proportions and the composition of the alkaline activator. External influences have large effects on the compressive strength of the geopolymer mortar. These effects are attributed to the amount of alkaline solution ratio 
$\left(\mathrm{Na}_{2} \mathrm{SiO}_{3} / \mathrm{NaOH}\right)$, and also the molarity of $\mathrm{NaOH}$ solution. Effect of solution to binder ratio, the molarity of $\mathrm{NaOH}$ solution and curing temperature was not investigated, but should be noted that they will also have significant effect on the compressive strength [7]. Fig. 4 shows the test results of the compressive strength of geopolymer mortar from different fly ash source. It was clearly shown that the ratio of $\mathrm{Na}_{2} \mathrm{SiO}_{3} / \mathrm{NaOH}$ have significant effect on the compressive strength of the geopolymer mortar. Lower ratio resulted in low compressive strength less than $20 \mathrm{MPa}$ with the exception of fly ash $\mathrm{Y} 11.2$. At $\mathrm{Na}_{2} \mathrm{SiO}_{3} / \mathrm{NaOH}$ ratio of 2, it was shown that the concrete have higher strength with fly ash Y11.2 could reach up to $98 \mathrm{MPa}$ for 14 days strength, while for other fly ash it could reach between 42 to $56 \mathrm{MPa}$. Fly ash Y11.2 produces much higher compressive strength compared to other fly ash, despite having exactly the same mixture. Given that the fly ash Y11.2 is the only high calcium fly ash in this study, it was more likely that the internal effect makes more difference in strength gain.
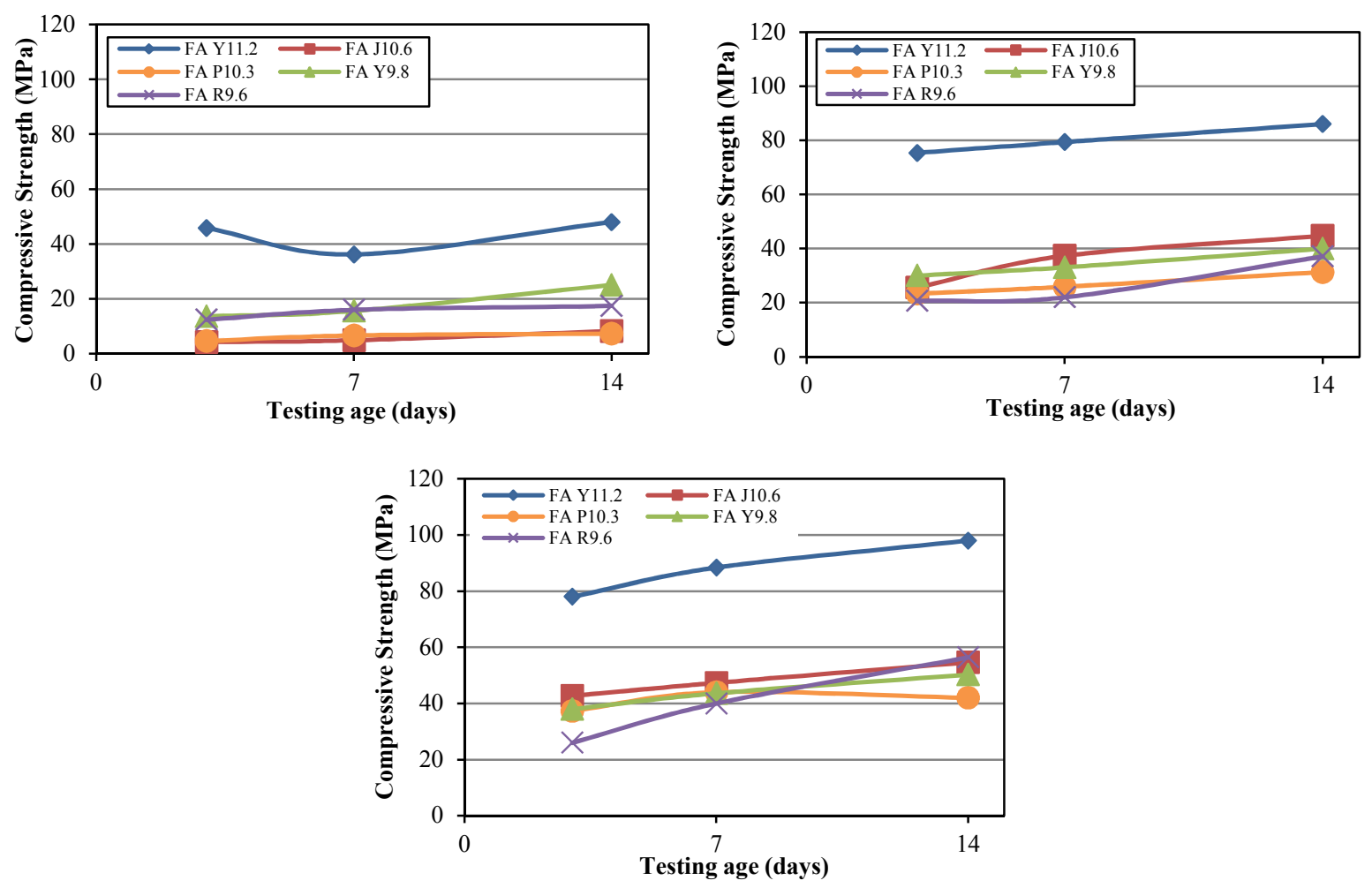

Figure 4. Compressive strength at 14 days for mortar made with different fly ash for ratio of $\mathrm{Na}_{2} \mathrm{SiO}_{3} / \mathrm{NaOH}$ at (a) 1 , (b) 1.5 and (c) 2 .

\section{Conclusions}

Compressive strength of geopolymer-based fly ash produced can be influenced by internal and external factors. Internal factors include the physical and chemical properties of fly ash. With more emphasis on the particle size distribution and its particle shape with finer particle would have higher reactivity and thus higher strength.

The chemical content of fly ash in the form of $\mathrm{CaO}$ and $\mathrm{MgO}$, from the results of this study, also showed a strong influence on compressive strength where high content of $\mathrm{CaO}$ and $\mathrm{MgO}$ increase the strength. Carbon content shown on the LOI value indicates lower value especially under $1 \%$, can produce higher compressive strength. However, further research is needed on this result because between compounds feared the dominant influence of a chemical compound that exist and influence the results obtained.

External factors such as mix design and process, which include alkaline solution and $\mathrm{NaOH}$ molarity used, can affect the compressive strength of geopolymer. With the lower alkali content and molarity of $\mathrm{NaOH}$, also produces lower compressive strength. 


\section{Acknowledgements}

The authors gratefully acknowledge The Directorate General for Higher Education, Ministry of Research, Technology and Higher Education, Indonesia, who provided the research grant through the 'Hibah Kompetensi' scheme in 2014 and 2015.

\section{Reference}

[1] J. Davidovits, Geopolymer chemistry and applications, 2nd ed. Saint-Quentin, France: Institute Géopolymère, 2008.

[2] J. J. Ekaputri, K. A. Priadana, T. E. Susanto, and S. Junaedi, "Physico-chemical characterization of fly ash," World Congr. Adv. Struct. Eng. Mech. Jeju, Korea, pp. 29882996, 2013.

[3] S. Kumar and R. Kumar, "Mechanical activation of fly ash: effect on reaction, structure and properties of resulting geopolymer," Ceram. Int., vol. 37, no. 2, pp. 533-541, 2011.

[4] J. J. Ekaputri, U. M. Bahrul, R. Bayuaji, S. T. Eddy, M. M. Al Bakri, and M. I. Triwulan, “A comprehensive characterization and determination of fly ashes in Indonesia using different methods," Appl. Mech. Mater., 2015.

[5] T. Phoo-ngernkham, P. Chindaprasirt, V. Sata, and T. Sinsiri, "High calcium fly ash geopolymer containing diatomite as additive," Indian J. Eng. Mater. Sci., vol. 20, no. 8, pp. 310-318, 2013.

[6] Antoni, R. Gunawan and D Hardjito, "Rapid Indicators in Detecting Variation of Fly Ash for Making HVFA Concrete” Appl. Mech. Mater. Vol. 815 (2015) pp 153-157

[7] M. Izquierdo and X. Querol, "Leaching behaviour of elements from coal combustion fly ash: An overview,” Int. J. Coal Geol., vol. 94, no. 5, pp. 54-66, May 2012.

[8] D. Hardjito and B. V. Rangan, "Development and properties of low-calcium fly ash-based geopolymer concrete," Curtin University of Technology. Perth, Australia, 2005.

[9] ASTM C618, Standard specification for coal fly ash and raw or calcined natural pozzolan for use in conrete. ASTM International, 2003.

[10]L. U. Duyou, Z. Yanzeng, L. I. U. Yongdao, and X. U. Zhongzi, "Effect of Light-burned Magnesium Oxide on Deformation Behavior of Geopolymer and its Mechanism," J. Chinese Ceram. Soc., vol. 40, no. 11, pp. 1625-1630, 2012. 